\section{Regards sur l'économie allemande}

Bulletin économique du CIRAC

116-117 | 2015

Varia

\title{
Humour au travail : bon pour la compétitivité !
}

Isabelle Bourgeois

\section{OpenEdition}

Journals

Édition électronique

URL : http://journals.openedition.org/rea/4832

DOI : $10.4000 /$ rea.4832

ISSN : 1965-0787

Éditeur

CIRAC

Édition imprimée

Date de publication : 1 juillet 2015

Pagination : 72

ISSN : 1156-8992

\section{Référence électronique}

Isabelle Bourgeois, « Humour au travail : bon pour la compétitivité ! », Regards sur l'économie allemande [En ligne], 116-117 | juillet 2015, mis en ligne le 01 juillet 2017, consulté le 15 septembre 2020. URL http://journals.openedition.org/rea/4832

Ce document a été généré automatiquement le 15 septembre 2020.

(c) CIRAC 


\title{
Humour au travail : bon pour la compétitivité !
}

\author{
Isabelle Bourgeois
}

L'index «HIHI », développé par l'institut de recherche IAB de Nuremberg (www.iab. de) pour mesurer l'effet de l'humour sur la qualité du travail et la compétitivité des entreprises, est en nette hausse en Allemagne, malgré un retard par rapport à des Etats comme le Royaume-Uni. La progression fulgurante du HIHI depuis 2005 a eu un impact très positif sur l'activité en phase conjoncturelle difficile : "L'humour, c'est quand on rit malgré tout». Mais tout est une question de degré : «Trop d'humour peut aussi avoir un impact négatif ", comme le fait apparaître une comparaison régionale qui révèle un très fort niveau du HIHI en Rhénanie (carnaval oblige ?). L'IAB va à l'avenir mieux étudier ce phénomène, annonce un communiqué de presse paru le... $1^{\mathrm{er}}$ avril 2015. Qui a dit que les Allemands manquent d'humour?

\section{INDEX}

Mots-clés : Compétitivité 